\title{
Molecular Mechanisms of Sexual Development
}

\author{
P. Parma ${ }^{a}$ O. Radi ${ }^{b}$ \\ a Department of Animal Science, Agricultural Faculty of Science, Milan University, Milan, and \\ ${ }^{b}$ Department of Pediatric Sciences and Human and Hereditary Pathology, Pavia University, Pavia, Italy
}

\section{Key Words}

$\beta$-Catenin · Gonadal development $\cdot$ Sex determination . SOX9.SRY

\begin{abstract}
Gonadal cellular organization is very similar in all vertebrates, though different processes can trigger bipotential gonads to develop into either testes or ovaries. While mammals and birds, apart from some exceptions, show genetic sex determination (GSD), other animals, like turtles and crocodiles, express temperature-dependent sex determination. In some groups of animals, GSD can also be overridden by hormone or temperature influences, indicating how fragile this system can be. This review aims to explain the fundamental molecular mechanisms involved in mammalian GSD, mainly referring to mouse as a major model. Conceivably, other mammals might show a molecular mechanism different from the commonly investigated murine species.
\end{abstract}

Copyright $\odot 2011$ S. Karger AG, Base

\section{Mammalian Sex Determination in 125 Words}

Sex in mammalian embryos is genetically determined at fertilization. When eggs are fertilized by sperm carrying an X or Y chromosome, a female and male phenotype develops, respectively. The male pathway is activated by a genetic factor, called testis-determining factor (TDF), which was identified more than 20 years ago as $S R Y$, a gene carried by the Y chromosome. First, SRY triggers a cascade of molecular events, the SOX9 pathway, inducing the undifferentiated urogenital ridge, a gonadal primordium characterizing all embryos, to differentiate into testis. Successively, some hormonal products from specific testis cells, i.e. anti-Müllerian hormone (AMH) by Sertoli cells and testosterone by Leydig cells, head male phenotype development of the embryo. In the absence of $S R Y$, a specific female molecular cascade, the $\beta$-catenin pathway, directs development of ovaries and female phenotype differentiation.

\section{First Steps in Sex Determination}

In both male and female murine embryos, the first sign related to sex development occurs at about 10.0 days post coitum (dpc) when a thickening of the epithelium, which gonadal somatic cells will derive from, appears along the coelomic surface of the mesonephros [Ross and Capel, 2005]. It is exactly when the XX and XY gonadal primordia show gonadal-specific gene expression, which is not sexually dimorphic until the activation of the malespecific pathway at $10.5 \mathrm{dpc}$. Knockout $(\mathrm{KO})$ experiments in mice have determined that some of these genes are responsible for the early proliferation of gonads in both sex-

\section{KARGER \\ Fax +41613061234 \\ E-Mail karger@karger.ch}

www.karger.com
(C) 2011 S. Karger AG, Basel

1661-5425/12/0063-0007\$38.00/0

Accessible online at:

www.karger.com/sxd
Dr. Pietro Parma

Department of Animal Science, Milan University

Via Celoria 2

IT-20133 Milan (Italy)

Tel.+390250316454,E-Mail pietro.parma@unimi.it 
es before participation of sex-specific genes, as their disruption causes gonad regression in both $\mathrm{XX}$ and $\mathrm{XY}$ embryos. These genes are: $E m \times 2$, Lhx9, Cbx2 (M33), SF1 (Nr5a1), Pod1, and insulin receptors (Insr, Igf1r, Insrr) [Luo et al., 1994; Miyamoto et al., 1997; Katoh-Fukui et al., 1998; Birk et al., 2000; Nef et al., 2003; Cui et al., 2004]. $\mathrm{KO}$ mice for these genes also show abnormal development of kidney and/or adrenal glands. Namely, the mesonephros, originating the gonad, derives from an intermediate mesoderm structure, the urogenital ridge, which includes pronephros, i.e. adrenal primordium, and metanephros, i.e. kidney primordium. This anatomical structure explains why mutations in gonad development often involve adrenal or kidney anomalies. Another gene, Wt1, is also related to early gonadal development in a more sophisticated way. In fact, $W t 1$ gives rise to several isoforms, originating by alternative splicing or by different translation start codons. Two among such isoforms are denoted by a very interesting behavior. They are called KTS+ and KTS- as their difference is due to in the presence or absence of a triplet of lysine-threonine-serine (KTS) amino acid residues [Wagner et al., 2003]. Wt1 KTS- KO mice show gonad regression of both XX and XY genotypes before $12.5 \mathrm{dpc}$ [Kreidberg et al., 1993], while in Wt1 KTS+ KO mice only XY embryos are affected as they develop a female phenotype [Hammes et al., 2001] as a consequence of absence of Sry activation or loss of stability. Thus, the action of $W t 1$ can be related to 2 different steps in sex determination. The KTS- variant is involved in the development of the early gonad, ahead of sex-specific pathway activation, while the KTS+ variant is implicated in the male-specific pathway only. At the end of this step, at 10.5 $\mathrm{dpc}$, several cells migrate from the mesonephros to the undifferentiated testis (a key step, together with cell proliferation), and successively they will be stimulated to differentiate into testis- or into ovary-specific cell lines. At that stage, a gonad can be influenced by the Sry gene, when present, and develop the typical architecture of vertebrate testis. If Sry is absent, another pathway can expand and direct ovary assembly. Thus, from $10.5 \mathrm{dpc}$ only 1 way is possible: the undifferentiated ridge can develop into a testis or into an ovary once and for all.

\section{SRY: The Godfather of Sex Determination}

At $10.5 \mathrm{dpc}$ a new actor, a gene discovered 20 years ago [Sinclair et al., 1990], shows up: Sry (sex-determining region of Y chromosome). Sry has been identified as the testis-determining factor (TDF), the key gene responsible for testis development in XY embryos. Its implication was clearly proved observing testis development in XX mice transgenic for Sry [Koopman et al., 1991]. Furthermore, $15 \%$ of XY human embryos developing a female phenotype as a result of testis development failure show mutation in this gene [Berta et al., 1990].

SRY, a chromatin remodeling transcription factor, is characterized by the presence of a DNA-binding domain containing a high-mobility group 1 (HMG) box. The presence of an HMG box, highly related to the SRY HMG box, characterizes a gene family called SOX (SRY-related HMG box). This functional domain is able to bind the (A/T)ACAA(T/A) DNA sequence and consequently to bend DNA with an angle of 60-85 [Harley and Goodfellow, 1994]. This DNA bending property is essential to carry out its biological function. If this function is blocked, the undifferentiated XY gonad fails to develop into a testis [Pontiggia et al., 1994]. The HMG box is the only part of the SRY gene conserved in different mammalian species. It is also the only functional part of this gene, as most $S R Y$ mutations leading to failure of testis development reside in this domain. XX mice carrying human $S R Y$ under the control of mouse regulatory sequences [Lovell-Badge et al., 2002] or goat $S R Y$ with its own regulatory elements [Pannetier et al., 2006] develop into males, indicating that SRY from different species probably acts in a similar way. The importance of the HMG box in promoting the biological function of SRY is confirmed by the fact that replacing the Sry HMG box with Sox3 or Sox 9 boxes causes sex reversal in transgenic XX mice [Bergstorm et al., 2000]. The SRY gene also possesses 2 nuclear localization signals (NLSs) placed at the $\mathrm{N}$ - and C-terminus of the HMG box domain, respectively. They are responsible for protein translocation into the nucleus, a key step in SRY function. Both NLSs are important, and they are not functionally redundant: a mutation involving just one of them is able to lead to testis development failure [Sim et al., 2005; Kaur and Jans, 2011]. These 2 NLSs recruit at least 2 proteins involved in SRY protein migration into the nucleus: calmodulin (NNLS), whose action mode is still unknown, and importin- $\beta$ (C-NLS), which facilitates transport through nuclear pore complexes [Harley et al., 1996; Forwood et al., 2001]. SRY also undergoes post-translational modifications; in particular, lysine acetylation and phosphorylation of 2 serines are the most relevant. Lysine (K136) acetylation promotes importin- $\beta$ recruitment, whereas a 2 -serine (S31, S33) modification increases the capacity to bind DNA and, consequently, transcription activity [Desclozeaux et al., 1998; Thevenet et al., 2004]. Finally, sev- 
eral in vitro experiments show that SRY could interact with other proteins (KRABO, SIP1, WT1, PARP1). The significance as well as the real in vivo existence of these interactions are still unclear, though. SRY triggers testicular tissue differentiation from the undifferentiated gonad, and its expression is very peculiar in terms of time and space. In fact, Sry expression begins at $10.5 \mathrm{dpc}$ in somatic cells of XY genital ridges, achieves its maximum level at $11.5 \mathrm{dpc}$, and comes to its end at $12.5 \mathrm{dpc}$ [Gubbay et al., 1990]. Moreover, Sry shows a particular wave-like expression pattern in the genital ridge, starting at its central regions and then extending to both poles, the last regions where Sry expression can be observed [Bullejos and Koopman, 2001]. Noticeably, this expression profile is the same even during Sry expression termination. Consequently, a single cell is exposed to Sry mRNA for less than $48 \mathrm{~h}$, i.e. the time span between 10.5 and $12.5 \mathrm{dpc}$. The Sry expression profile has to be precisely performed to maintain its proper function. In fact, any delay in its expression fails to induce a correct testis development, as clearly demonstrated by Hiramatsu et al. [2009] in transgenic mice carrying the Sry gene under the control of an inducible promoter (Hsp70.3). Even a 6-hour delay in Sry expression leads to a failure in testis development. The importance of respecting the critical window of Sry expression was also demonstrated observing the phenotypes of $\mathrm{B} 6 / \mathrm{Y}^{\mathrm{DOM}}$ mice. $\mathrm{Y}^{\mathrm{DOM}}$ mice, carrying a specific Y-chromosome variant with a delayed Sry expression of about $10 \mathrm{~h}$, are crossed into C57BL/6J (B6) genetic background. $\mathrm{B} 6 / \mathrm{Y}^{\mathrm{DOM}}$ mice show a variety of phenotypes that include both ovary and ovotestis [Eicher et al., 1992; Bullejos and Koopman, 2005].

However, while a delayed expression of Sry seems to be very important in inducing critical effects in testis differentiation, no relevant events seem to derive from a premature expression of Sry. Inducing Sry expression before $10.5 \mathrm{dpc}$ does not lead to either premature testis development or to activation of male-specific genes, which suggests that co-factors available from $10.5 \mathrm{dpc}$ are needed for the action of SRY [Kidokoro et al., 2005]. As reported above, while the beginning of $S R Y$ expression is a critical parameter, its duration does not seem to be meaningful as several mammals show a persistent SRY expression beyond testis development. This expression profile was reported in goats [Pannetier et al., 2006], pigs [Parma et al., 1999], sheep [Payen et al., 1996], humans [Hanley et al., 2000], rabbits [Díaz-Hernández et al., 2008], and cattle [Ross et al., 2009]. The function of such persistent expression in these species is still unknown; though, a recent study performed in goats suggests its possible influence on male fertility and testicular maintenance [MontazerTorbati et al., 2010]. Exact temporal expression of $S R Y$ is not the only critical parameter; in fact, its quantity is similarly significant, as failure in testis differentiation occurs when a required threshold is not achieved. Although its precise mechanism of action is still unknown, several genes have been related to Sry regulation; e.g. its expression is decreased when factors such as GATA4, FOG2, CBX2, MAP3K4, insulin receptors, and WT1 (KTS+ variant) are inactivated in mice [Katoh-Fukui et al., 1998; Crispino et al., 2001; Hammes et al., 2001; Tevosian et al., 2002; Nef et al., 2003; Bogani et al., 2009; Manuylov et al., 2011]

Sry is expressed in the somatic cells of the XY genital ridge, inducing them to differentiate into Sertoli cells. Such cells are considered as the organizational center for the testis. In fact, they transmit signals to other precursor lineages to make them differentiate into other testis cell lines, and they draw cell migration from the mesonephros to set up male-specific vasculature [Coveney et al., 2008; Combes et al., 2009]. Another key step in testis differentiation consists in reaching a threshold number of Sertoli cells; chimera experiments (XX/XY) show that $30 \% \mathrm{XY}$ cells are necessary for the gonad to develop into testis [cited by Brennan and Capel, 2004]. Moreover, it has been observed that shortly after Sry expression, all SRY-positive cells changed into Sertoli cells [Sekido et al., 2004], but not all Sertoli cells were SRY-positive [Palmer and Burgoyne, 1991], an observation suggesting the existence of paracrine signals supporting the action of SRY in the recruitment of Sertoli cells during testis formation, as described below.

To recap, SRY can act as TDF only under the following conditions: (a) SRY-scheduled time expression profiles must be precisely respected; (b) a threshold expression of $S R Y$ must be reached; (c) SRY migration in the nucleus must occur properly; (d) a discrete number of Sertoli cells must be differentiated. If these steps are fulfilled, SRY activates SOX9, and cells exposed directly to SRY or recruited by PGD2 pathway start to differentiate into Sertoli cells. At this point, only 1 chance is given to mammalian sex determination, which means that the gonad can develop exclusively into a testis.

In conclusion, SRY acts as a switch for male/female differentiating pathways and is crucial to activate SOX9, the autosomal gene responsible for heading Sertoli cell differentiation and subsequent formation of testis architecture.

Nevertheless, $S R Y$ is not conserved in all vertebrates; as a consequence, the molecular switch for male/female 
pathways must be performed by other actors. In birds, homogametic sex is male (ZZ), while heterogametic sex is female $(\mathrm{ZW})$. In the absence of $S R Y$, the molecular switch seems to be played by DMRT1, a gene homologous to the Drosophila sex regulatory gene doublesex and to Caenorhabditis sex regulator mab-3. In fact, reduction of DMRT1 protein expression in chicken leads to partial sex reversal of embryonic ZZ male gonads and to SOX9 expression reduction, indicating that DMRT1 acts through a dosage-sensitive mechanism [Smith et al., 2009]. In addition, in Medaka fish, where an XX/XY genetic mechanism underlies sex determination unlike some other fish, a DMRT1-like gene, $d m r t 1 b Y$, triggers testis development [Matsuda et al., 2002]. Recently, Yoshimoto et al. [2010] isolated a W-linked gene, $D M-W$, as a paralogue of $D m r t 1$ in Xenopus laevis, which shows a ZZ/ZW-type sex-determining system. The authors proposed that Dmrtl drives the expression of specific testis genes in $\mathrm{ZZ}$ gonads, while in ZW gonads DM-W, having no transactivation domain, acts as a trans-dominant negative factor and leads to repression of male-specific genes.

Intriguingly, deletion of the DMRT1 locus in human chromosome 9p leads to XY gonadal dysgenesis [Raymond et al., 1999]. On the other hand, Dmrt1 null mice show a mild phenotype characterized by post-natal testis defects [Raymond et al., 2000]. Thus, DMRT1 involvement in mammalian sex determination is far from being clear.

\section{SOX9: The Godfather's Yes-Man of Testis Differentiation}

After over 20 years from its identification, the only ascertained direct target for SRY is SOX9. Unlike SRY, specific for mammals only, SOX9 is conserved in many species [Morais da Silva et al., 1996] and much evidence demonstrated that it can direct testis development in mammals as well as in other vertebrates. Intriguingly, a Drosophila Sox9 homologue, Sox100B, revealed to be essential for somatic testis differentiation [Nanda et al., 2009]. Sox9 gain-of-function mutations switch male differentiation in XX gonads even in the absence of Sry inasmuch as in mice Sox9 ectopic expression in XX gonads is sufficient to induce Sertoli cell differentiation and testis morphogenesis [Vidal et al., 2001]. A similar phenotype is described in transgenic mice carrying an insertion $1 \mathrm{Mb}$ upstream of Sox 9 that performs a long-range effect on a gonad-specific enhancer, inducing over-expression of Sox9 [Bishop et al., 2000]. In humans, only 1 case of
SOX9 duplication has been described in a $46, \mathrm{XX}$ sex reversal patient [Huang et al., 1999], while a very recent description of a SOX9 upstream duplication in a family showing 3 cases of 46,XX testicular disorder, with no other phenotypes, suggests the presence of sex-specific regulatory elements localized at the $5^{\prime}$ end of the gene, able to activate Sox9 gonad expression [Cox et al., 2011]. First evidence for the role of SOX9 in testis development came from the observation of SOX 9 heterozygous mutations responsible for campomelic dysplasia (MIM 114290), a congenital skeletal disorder associated with various defects in testicular differentiation, up to complete male-tofemale sex reversal phenotype in about $75 \%$ of XY patients [Foster et al., 1994]. However, heterozygous loss-offunction mutations do not cause sex reversal in mice, while homozygous embryos die at $11.5 \mathrm{dpc}$, when gonadal sex determination occurs. Experiments on conditional mutants demonstrated that Sox9 homozygous specific inactivation in developing gonads interferes with Sertoli cell differentiation and testis cord formation, and gene expression analysis reveals down-regulation of male markers and up-regulation of ovarian factors as a sign of gonad sex reversal [Chaboissier et al., 2004; Barrionuevo et al., 2006]. More recent studies indicate that Sox9 XY mutant gonads show an intermediate transcription profile between male and female gonads at $13.5 \mathrm{dpc}$. Moreover, follicles develop in mutant XY ovaries and some XY mutant females are partially fertile and produce viable offspring [Lavery et al., 2011].

SOX9 protein contains a highly conserved HMG box domain [Gubbay et al., 1990], including 2 NLSs [Sim et al., 2008] that interact with calmodulin (the N-terminal NLS) and with importin- $\beta$ (the C-terminal NLS), as previously described for SRY, and a C-terminal transactivation domain [Südbeck et al., 1996].

In mice, very low levels of Sox 9 expression were observed in the genital ridge of both sexes at $10.5 \mathrm{dpc}$, when Sry expression is at its very early activation. By $11.5 \mathrm{dpc}$, Sox9 expression is absent in $\mathrm{XX}$ genital ridges, while it is up-regulated in XY genital ridges to support Sertoli cell lineage differentiation. Moreover, Sox9 expression is maintained also after the Sry expression window is closed [Morais da Silva et al., 1996; Sekido et al., 2004]. This implies the existence of mechanisms for Sox9 expression regulation and maintenance other than the mechanism SRY can provide. SF1 was supposed to have a role in initiating Sox9 expression because early sex-independent expression of Sox9 is lost in SF1 (Nr5a1) mutant gonads [Sekido et al., 2004]. Recent results confirmed that SF1 is required for up-regulation of Sox9, acting synergically 
with SRY on a Sox9 testis-specific enhancer (TESCO, testis-specific enhancer of Sox9 core element), and that in turn SOX9, together with SF1, maintains its own expression by an auto-regulatory loop [Sekido and LovellBadge, 2008]. On the other hand, in vitro co-transfection studies suggest that SOX9 is required for the male-specific expression of $S F 1$ [Shen and Ingraham, 2002]. Anyway, analysis of animal models highlighted other characters playing on this scenario. Fgf9 mutant mice show that SOX9-positive loop is not sufficient to maintain its own expression. In this animal model, in fact, although Sry is correctly activated and Sox9 levels are normal up to 11.5 $\mathrm{dpc}$, Sox9 expression is not maintained afterward, causing abortion of male differentiation pathway and change of somatic cells into a female program [Colvin et al., 2001; Schmahl et al., 2004]. In turn, Fgf9 expression is downregulated at $11.5 \mathrm{dpc}$ in cultured gonads from Sox $9 \mathrm{mu}-$ tant mice [Kim et al., 2006], and these findings associate the 2 genes in a feed-forward mechanism. FGF9 is a member of the fibroblast growth factor family; it is known to have mitogenic capacities in a number of cell types and is expressed in different proliferating regions [Colvin et al., 1999]. During sexual development Fgf9 is expressed in both XX and XY gonads at $11.5 \mathrm{dpc}$; then, $\mathrm{Fg} f 9$ expression becomes specific of XY gonads at $12.5 \mathrm{dpc}$. The most relevant cellular effect of $F g f 9$ ablation is male-specific reduction of proliferation in the coelomic epithelium [Schmahl et al., 2004]. It may act as a paracrine factor to recruit nearby cells to Sertoli fate by its receptor FGFR2 [Kim et al., 2007; Bagheri-Fam et al., 2008], increasing the number of Sertoli precursors above the critical threshold needed for testis development. By $11.2 \mathrm{dpc}$, FGFR2 is localized in the cell membrane of most proliferating coelomic epithelial cells in both XX and XY gonads, while at $11.5 \mathrm{dpc}$ FGFR2 is present in the nucleus of Sertoli precursor cells scattered in the interior of XY gonads. In Fgf9 mutant mice, nuclear localization of FGFR2 is lost, indicating that it is dependent on FGF9 [Schmahl et al., 2004].

Another molecular signal seemingly involved in the recruitment of Sertoli cells during testis differentiation is prostaglandin D2 (PGD2). The exposure of cultured fetal mouse XX gonads to PGD2 resulted in Sox9 expression, while Sox9 expression was blocked in the presence of an inhibitor of PGD2 receptor [Wilhelm et al., 2005]. Moreover, it has been suggested that prostaglandin D2 synthase (PTGDS), an enzyme required to synthesize PGD2, is a direct target of SOX9 in Sertoli cells. SOX9 has been demonstrated to activate the Ptgds promoter in reporter assays, and SOX9 protein can bind Ptgds promoter in vivo [Wilhelm et al., 2007]. On the other hand, Ptgds ${ }^{-1-} \mathrm{XY}$ gonads exhibit reduced levels of Sox9 transcription in vivo, but not complete sex reversal. Such findings suggest that PGD2-mediated signal is necessary to reinforce the recruitment of supporting cell precursors toward Sertoli cell fate [Moniot et al., 2009]. In Sertoli cells, SOX9 activates AMH transcription, a member of TGF- $\beta$ superfamily, responsible for Müllerian duct regression [Knower et al., 2003]. Concomitantly to the differentiation of Sertoli cells, a number of cellular events critical for testis morphogenesis occur in male gonads. Increased proliferation of interstitial cells, together with cell migration from the mesonephros, plays a crucial role in the development of testis cords, necessary for germ cell growth and maturation. Studies on cultured gonads demonstrated that, when blocking cellular migration from mesonephros at $11.5 \mathrm{dpc}$, testis cords do not develop properly [Buehr et al., 1993; Tilmann and Capel, 1999].

Migrating cells are mainly endothelial cells gathering within the gonad to give shape to a male-specific arterial network, branched from coelomic blood vessel. This vascular system is fundamental for testis growth and hormonal product distribution. Cell migration from the mesonephros should be regulated by PDGF (platelet-derived growth factor). Indeed, null mice for PDGF receptor $\left(P d g f^{-/-}\right)$show defects in cell migration and vascularization [Brennan et al., 2003].

Between 12.5 and $13.5 \mathrm{dpc}$, fetal Leydig cells, responsible for steroidogenesis, start to differentiate in the interstitial region of the XY gonad. At $11.5 \mathrm{dpc}, \mathrm{SF} 1$ is expressed both in pre-Sertoli and pre-Leydig cell lines. Subsequently, SF1 expression decreases in Sertoli cells and increases in differentiating Leydig cells, regulating genes involved in steroidogenesis [Hatano et al., 1994].

It was demonstrated that desert hedgehog gene $(\mathrm{DHH})$ and PDGF receptor are male-specific factors required for early differentiation and expansion of the Leydig cell lineage.

Dhh and $P d g f$ are expressed in Sertoli cells, while their corresponding receptor genes (Ptch1 and Pdgfr, respectively) are expressed in the interstitium. Mutants in both $D h h$ and $P d g f r$ show defects in testis architecture and severe impairment of fetal Leydig cell differentiation [Bitgood et al., 1996; Yao et al., 2002; Brennan et al., 2003].

\section{$\beta$-Catenin: The Pink Side of the Family}

In 1947, Alfred Jost demonstrated by his renowned experiments on rabbits that male sex phenotypic development requires the presence of testes, while female sex 
phenotypic development is able to proceed even in the absence of ovaries, which suggests the existence of an active genetic program for male phenotype differentiation against a default pathway for the female differentiation process [Jost, 1947].

Following TDF localization on the Y chromosome, Jost's hypothesis was translated from phenotype to gonad, and some authors postulated an active genetic mechanism for testis development and a passive mechanism for ovary differentiation. Several physiological and experimental evidences then contributed to erode the bases of this dogma in time. The existence of sex reversal syndromes, characterized by testis development and male phenotype in 46,XX subjects without $S R Y$, suggests the existence of a genetically active program in XX gonads. This process, which may lead ovary differentiation and/ or repress the testis developmental pathway, when disrupted could cause male genetic program activation in chromosomally female gonads.

A great number of genes that correctly coordinate processes as cell differentiation, migration, proliferation, and apoptosis are necessary to perform the development of such a complex organ as an ovary, with its morphologically and functionally specialized cell lineages organized into a precise conformation. Differential expression analyses in embryonic mice gonads during the critical sex determination period (10.5-13.5 dpc) demonstrated overexpression of 1,223 genes specifically in XX gonads, indicating the activation of a robust differentiation program also in female gonads [Nef et al., 2005]. Mutational analyses in humans and in animal models led to the identification of some genes involved in the early phases of ovary determination and differentiation.

$D A X 1$, a member of the nuclear hormone receptor superfamily, appeared to be an ideal candidate for an ovarydetermining factor, being localized on chromosome $\mathrm{X}$ and identified in duplications in XY subjects characterized by male-to-female sex reversal [Bardoni et al., 1994; Zanaria et al., 1995]. Moreover, XY transgenic mice carrying extra copies of Dax1 show complete sex reversal [Swain et al., 1998]. On the other hand, analyses of animal models carrying loss-of-function mutations demonstrated that this gene is not necessary for ovary development, while it is required for testis differentiation. Indeed, null mutations of Dax1 in XX embryos do not affect ovarian development or fertility [Yu et al., 1998], but can cause complete male-to-female sex reversal in some XY genetic backgrounds [Meeks et al., 2003; Bouma et al., 2005].

Another candidate ovary gene was initially identified in goats as a factor causing polled intersex syndrome
(PIS). XX goats carrying homozygous Polled mutation showed female-to-male sex reversal in absence of SRY, associated with lack of horns. Mapping of the PIS locus in goats led to the identification of an 11.7-kb deletion that affects the transcription of FOXL2 [Pailhoux et al., 2001]. In humans, mutation of FOXL2 is responsible for blepharophimosis ptosis epicantus inversus syndrome (BPES) associated with premature ovarian failure [Crisponi et al., 2001]. FOXL2 is a basic helix-loop-helix transcription factor belonging to the forkhead/winged helix nuclear transcription factor family. In mice, Foxl2 is specifically expressed in XX gonads by $12.5 \mathrm{dpc}$, mainly localized in committed pre-granulosa supporting cells [Schmidt et al., 2004], but null mutations do not seem to affect initial ovary development, while in Foxl2 mutant ovaries defects in folliculogenesis become apparent in late development [Ottolenghi et al., 2005]. Moreover, Foxl2 null mice show a reduced expression of the follistatin gene (Fst) in postnatal ovaries, while over-expression of Foxl2 in mice results in an increase of Fst expression in XX gonads [Garcia-Ortiz et al., 2009]. Fst, a member of the TGF- $\beta$ binding factor superfamily, plays an earlier role in ovarian development, as Fst null mice show partial XX sex reversal [Yao et al., 2004]. It was demonstrated by in vitro experiments that Foxl2 up-regulates Fst expression cooperatively with $B m p 2$; moreover, Bmp2 up-regulates Fst expression in ex vivo organ culture experiments [Kashimada et al., 2011]. However, recent results showed that conditional ablation of Foxl2 in adult gonads determines an ovary-to-testis trans-differentiation of the somatic lineages. The mRNA expression profile of these mutant gonads shows the expression of testis-specific markers, including Daxl, Dhh, Dmrtl, and notably Sox9 [Uhlenhaut et al., 2009]. This adulthood trans-differentiation seems to be driven by the activation of a Sox9 testis-specific enhancer, TESCO, suggesting that FOXL2 may repress in vivo Sox9 expression through TESCO binding. Moreover, estrogen receptor 1 (ESR1) seems to synergize with FOXL2 to repress TESCO regulatory element [Uhlenhaut et al., 2009]. Estrogens can induce male-tofemale sex reversal in vertebrate species with geneticbased sex determination mechanisms as fish, reptiles and birds, but not in most eutherian mammals [Barske and Capel, 2008]. On the other hand, in goats FOXL2 activates $\mathrm{P} 450$ aromatase gene transcription in early fetal ovary and the PIS phenotype is characterized by an earlier ovary phenotype than in Foxl2 null mutant XX mice. These findings suggest that estrogen activity could be a predominant anti-testis or ovary-determining mechanism in goats. 
WNT4 is one of the first best characterized markers for ovarian differentiation. WNT4 is a member of Wnt secreted signal molecules, which function as short-range ligands to locally activate receptor-mediated signaling pathway, and are involved in several embryonic developmental processes. The best known Wnt signaling pathway stabilizes $\beta$-catenin and activates LEF/TCF (lymphocyte enhancer factor/T-cell factor)-dependent transcription of downstream genes [Verheyen and Gottardi, 2010].

In mice, Wnt4 is early expressed in the mesenchyme of mesonephros, but not in mesonephric tubules, and in the coelomic epithelium of gonadal anlagen during the bi-potential stage. When gonad sex differentiation starts at $11.5 \mathrm{dpc}$, expression decreases in male developing gonads, but persists in XX gonads and in the mesenchyme surrounding Müllerian ducts. In contrast to gonads, Wnt4 is expressed in mesonephric mesenchyme of both sexes, and in mesenchyme cells underlying Müllerian ducts, while it is absent in Wolffian ducts [Vainio et al., 1999].

Wnt4 null XX mice show only a partial sex reversal phenotype: Müllerian ducts are absent and Wolffian ducts continue to develop, but no masculinization of external genitals was observed at birth [Vainio et al., 1999]. Mutant XX gonads develop a not-branched blood vessel resembling testis coelomic vessel and show the presence of steroidogenic cells derived from adrenal precursor [Jeays-Ward et al., 2003]. Sox9 expression is initially upregulated at $11.5 \mathrm{dpc}$, but rapidly down-regulated at 12.0 $\mathrm{dpc}$ and absent at $12.5 \mathrm{dpc}$ [Kim et al., 2006]. Analysis of transgenic mice showed that gain-of-function mutation in XY gonads does not inhibit initial development of the coelomic vessel, but that it interferes with normal branching of testis vasculature [Jeays-Ward et al., 2003]. WNT4 antagonizes male vasculature development through the downstream effector FST [Yao et al., 2004]. In the ovary, WNT4 and FST repress inhibin beta-B (Inhbb), which in $\mathrm{XY}$ gonads is involved in the formation of the male coelomic vessel [Yao et al., 2006]. In humans, rare mutations in WNT4 have been described in female patients with defects in Müllerian duct development and clinical signs of androgen excess [Biason-Lauber et al., 2004]. Such evidences indicate that WNT4 is involved in Müllerian duct development and represses endothelial cell migration and coelomic vessel formation in XX gonads, but it does not function alone as a primary ovarian determining gene or as an opponent of the testis developmental pathway.

Molecular Mechanisms of Sexual

Development
The double ablation of Foxl2 and Wnt4 genes in mouse XX gonads induces the development of ovotestes: testislike tubules, expressing high levels of testis-specific genes as Sox9 and Amh and containing differentiated spermatogonia, are present in the medullary region of the gonad, while in the cortical region, germ cells resemble late prophase oocytes, expressing meiotic markers [Ottolenghi et al., 2007]. Thus, sex reversal in these double mutant $\mathrm{XX}$ gonads is more evident than in single knockouts, indicating that FOXL2 and WNT4 could act through complementary pathways to repress the male fate in differentiating ovaries. Nevertheless, the incomplete phenotype suggests the existence of other ovarian factors needed to trigger ovary development and to oppose the male differentiation pathway in XX gonads.

In humans, the only gene found whose loss-of-function mutations cause testis development in XX patients, is $R$-spondin 1 . In 2 independent cases, homozygous mutations of RSPO1 were identified in XX subjects with complete female-to-male sex reversal, associated with skin defects [Parma et al., 2006].

In the absence of SRY, the gonads of these patients developed as functional testes, as shown by the absence of Müllerian derivatives and by internal and external genital masculinization. Moreover, RSPO1 is required neither for male differentiation nor for fertility in XY subjects [Radi et al., 2005; Parma et al., 2006]. Expression analyses on embryonic murine gonads demonstrated expression of Rspo1 in the urogenital ridge as early as $10.5 \mathrm{dpc}$ in the coelomic epithelium. By $11.5 \mathrm{dpc}$ sex-specific expression appears in the somatic cells of the XX gonads [Parma et al., 2006].

Studies on Rspo1 null animal models clarified some aspects of RSPO1 action in gonadal sex determination and ovary development. Rspol KO XX gonads develop as ovotestes, containing seminiferous tubules together with nests of pachytene oocytes, and adult mice show masculinized external genitalia and persistence of both Müllerian and Wolffian ducts [Chassot et al., 2008; Tomizuka et al., 2008].

A differential expression analysis of genes involved in sex determination was performed in XX Rspol mutant gonads versus wild-type gonads. Female markers, as Bmp2 and Foxl2, do not show relevant differences between mutated and normal gonads, indicating a partial conservation of a female identity in the somatic lineage, even in the absence of RSPO1. On the contrary, male markers (Fgf9, Pgds, Sox9, Amh) exhibit an increased expression in Rspo1 mutant mice, suggesting that in XX gonads RSPO1 acts as a suppressor of the male differentiation pathway.

Sex Dev 2012;6:7-17 
RSPO1 is a member of the protein family of R-spondins involved in the embryonic development of different organs [Nam et al., 2007]. They are secreted proteins that stabilize $\beta$-catenin through receptor interactions.

Analysis of mutant mice demonstrated that RSPO1 triggers female gonadal sex determination through $\beta$ catenin stabilization. Indeed, in Rspol null mice XX gonads show a reduced regulation of $\beta$-catenin-specific targets (Lef1 and Axin), and the mutant phenotype of XX $R s p o 1^{-1-}$ gonads is rescued by ectopic activation of $\beta$ catenin [Chassot et al., 2008]. The major role of the $\beta$ catenin pathway in sex determination of XX gonads was demonstrated by analysis of animal models. Ectopic expression of a dominant stable $\beta$-catenin allele in XY gonads is sufficient to disrupt male differentiation and induce ovary development [Maatouk et al., 2008]. On the other hand, specific inactivation of $\beta$-catenin in the putative precursors of granulosa cells causes defects in ovary differentiation, and mice show a phenotype similar to Wnt4 and to Rspo1 mutant mice [Tevosian and Manuylov, 2008; Liu et al., 2009].

$\beta$-Catenin is an intracellular bi-functional protein involved in cell-cell adhesion interactions; it also functions as a nuclear transcription factor. The major part of $\beta$ catenin is associated with cadherins within the adherent junctions, as a component of the cytoskeleton. However, a little dynamic pool of $\beta$-catenin shuttles between cytoplasm and nucleus to transduce the canonical Wnt signal [Kimelman and Xu, 2006]. The crucial point of Wnt signal transduction engages the inhibition of the constitutive degradation mechanisms. In the presence of Wnt signal, stable $\beta$-catenin translocates into the nucleus and regulates target gene expression by binding DNA through the nuclear transcription complex LEF/TCF. In cells not exposed to Wnt signal, the cytosolic pool of $\beta$-catenin is kept at low levels through degradation mediated by the ubiquitin pathway. Removing $\beta$-catenin from the LEF/ TCF complex allows access to co-repressors inhibiting transcriptional function [Cavallo et al., 1998; Roose et al., 1998].

Unlike the XY gonad, where dramatic changes follow Sry expression, very few morphological changes occur in the female gonad until close to birth. In the ovary 2 regions can be distinguished: the cortex and the medulla, even if this distinction is not well appreciable at $12.5 \mathrm{dpc}$. Primordial germ cells, clustered in germ cell nests, localize in the cortex, while in the medullary region they undergo apoptosis. The first cellular event specific for the $\mathrm{XX}$ gonad is the entry of germ cells into meiosis, which in mice occurs between 13.5 and $14.5 \mathrm{dpc}$. It was demon- strated that the entry of XX germ cells into meiosis is induced by retinoic acid. In the male gonad, entry into meiosis is prevented by up-regulation of CYP26B1, an enzyme that degrades retinoic acid [Bowles et al., 2006].

In fetal ovary, a coordinate action of secreted (RSPO1/ WNT4) and intracellular (FOXL2) factors specifies and maintains the identity of granulosa cells, the somatic cell lineage derived from the same precursors as testis Sertoli cells.

\section{Fights between Rival Gangs}

In a bipotential gonad, a precarious equilibrium is established between factors needed for testis or ovary development, and the presence or absence of the Y chromosome leads the balance toward male or female mode. SRY activates SOX9 transcription (maintained and reinforced through a feed-forward loop involving FGF9 and PGD2) that in turn activates Sertoli cell differentiation and, thus, testis development. Nevertheless, SRY must be active in a definite time slot. Otherwise RSPO1 and WNT4, through $\beta$-catenin stabilization, together with FOXL2 establish and maintain the female differentiating pathway of somatic cell progenitors by antagonizing SOX 9 expression. Molecular pathways of ovary and testis determination reciprocally cross at different levels. FGF9 and WNT4 act antagonistically: exogenous FGF9 exposure of gonadal systems induces Sox9 expression and blocks Wnt4 expression, suggesting that FGF9 acts both recruiting gonadal cells into a male differentiation program and blocking female signals. In turn, WNT4 is involved in male pathway repression. Indeed, $F g f 9$ results de-repressed in Wnt4 mutant XX gonads, where Sox 9 expression is activated in the absence of SRY [Kim et al., 2006].

The bipotential gonad hangs in the balance between 2 fates, both generated by extracellular signals and by an intracellular antagonism based on the relative equilibrium between $\beta$-catenin and SOX9 amounts, a mechanism demonstrated to be involved in chondrocyte differentiation [Akiyama et al., 2002].

Similarly, in the bipotential gonad $\beta$-catenin and SOX9 could be proposed as executive antagonistic molecules between female and male pathways, directing somatic precursors towards either granulosa or Sertoli cells. Anyway, such complex and multifactorial regulations, reciprocally positive and negative, suggest the existence of accessory 'remote controls' reinforcing these pathways.

A bipotential gonad is the only embryonic structure that can originate 2 different organs such as testis and 
ovary. After an early phase of strength balance, when several factors contribute to raise the gonadal anlagen, the critical point for sex development, i.e. gonadal sex determination, coincides with the deployment of forces by 2 distinct and antagonistic molecular pathways, determined to prime gonadal differentiation toward a testis or an ovary. A crucial point for the genetic control of sex determination stands in the enhancement of one path- way, coherent with the chromosomal sex, so that the opposite pathway cannot take control of the gonad.

SOX9 and $\beta$-catenin pathways seem to be the 2 major mechanisms involved in this sort of fight. Though, many other components are not answering the roll call, as several human patients affected by disorders concerning sexual development do not have a genetic diagnosis.

\section{References}

Akiyama H, Chaboissier MC, Martin JF, Schedl A, de Crombrugghe B: The transcription factor Sox 9 has essential roles in successive steps of the chondrocyte differentiation pathway and is required for expression of Sox5 and Sox6. Genes Dev 16:2813-2828 (2002).

-Bagheri-Fam S, Sim H, Bernard P, Jayakody I, Taketo MM, et al: Loss of Fgfr2 leads to partial XY sex reversal. Dev Biol 314:71-83 (2008).

-Bardoni B, Zanaria E, Guioli S, Floridia G, Worley KC, et al: A dosage sensitive locus at chromosome Xp21 is involved in male to female sex reversal. Nat Genet 7:497-501 (1994).

-Barrionuevo F, Bagheri-Fam S, Klattig J, Kist R, Taketo M, et al: Homozygous inactivation of Sox9 causes complete XY sex reversal in mice. Biol Reprod 74:195-201 (2006).

Barske LA, Capel B: Blurring the edges in vertebrate sex determination. Curr Opin Genet Dev 18:499-505 (2008).

Bergstrom DE, Young M, Albrecht KH, Eicher EM: Related function of mouse SOX3, SOX9, and SRY HMG domains assayed by male sex determination. Genesis 28:111-124 (2000).

- Berta P, Hawkins JR, Sinclair AH, Taylor A, Griffiths BL, et al: Genetic evidence equating $S R Y$ and the testis-determining factor. Nature 348:448-450 (1990).

Biason-Lauber A, Konrad D, Navratil F, Schoenle EJ: A WNT4 mutation associated with Müllerian-duct regression and virilization in a 46,XX woman. N Engl J Med 351:792798 (2004)

-Birk O, Casiano D, Wassif C, Cogliati T, Zhao L, et al: The LIM homeobox gene $L h x 9$ is essential for mouse gonad formation. Nature 403: 909-913 (2000).

- Bishop CE, Whitworth DJ, Qin Y, Agoulnik AI, Agoulnik IU, et al: A transgenic insertion upstream of Sox9 is associated with dominant XX sex reversal in the mouse. Nat Genet 26:490-494 (2000).

-Bitgood MJ, Shen L, McMahon AP: Sertoli cell signaling by Desert hedgehog regulates the male germline. Curr Biol 6:298-304 (1996).
Bogani D, Siggers P, Brixey R, Warr N, Beddow $\mathrm{S}$, et al: Loss of mitogen-activated protein kinase kinase kinase 4 (MAP3K4) reveals a requirement for MAPK signalling in mouse sex determination. PLoS Biol 7:1-19 (2009).

Bouma G, Albrecht K, Washburn L, Recknagel A, Churchill G, et al: Gonadal sex reversal in mutant Dax1 XY mice: a failure to upregulate Sox9 in pre-Sertoli cells. Development 132:3045-3054 (2005).

Bowles J, Knight D, Smith C, Wilhelm D, Richman J, Mamiya S, et al: Retinoid signalling determines germ cell fate in mice. Science 312:596-600 (2006).

- Brennan J, Capel B: One tissue, two fates: molecular genetic events that underlie testis versus ovary development. Nat Rev Genet 5: 509-521 (2004).

- Brennan J, Tilmann C, Capel B: Pdgfr-alpha mediates testis cord organization and fetal Leydig cell development in the XY gonad. Genes Dev 17:800-810 (2003).

Buehr M, Gu S, McLaren A: Mesonephric contribution to testis differentiation in the fetal mouse. Development 117:273-281 (1993).

-Bullejos M, Koopman P: Spatially dynamic expression of Sry in mouse genital ridges. Dev Dyn 221:201-205 (2001).

Bullejos M, Koopman P: Delayed Sry and Sox9 expression in developing mouse gonads underlies B6-Y(DOM) sex reversal. Dev Biol 278:473-481 (2005)

Cavallo RA, Cox RT, Moline MM, Roose J, Polevoy GA, et al: Drosophila Tcf and Groucho interact to repress Wingless signalling activity. Nature 395:604-608 (1998).

- Chaboissier M, Kobayashi A, Vidal V, Lützkendorf S, van de Kant H, et al: Functional analysis of Sox8 and Sox 9 during sex determination in the mouse. Development 131:18911901 (2004).

Chassot A, Ranc F, Gregoire E, Roepers-Gajadien R, Taketo M, et al: Activation of $\beta$-catenin signaling by Rspol controls differentiation of the mammalian ovary. Hum Mol Genet 17:1264-1277 (2008)

-Colvin JS, Feldman B, Nadeau JH, Goldfarb M, Ornitz DM: Genomic organization and embryonic expression of the mouse fibroblast growth factor 9 gene. Dev Dyn 216:72-88 (1999)
Colvin JS, Green RP, Schmahl J, Capel B, Ornitz DM: Male-to-female sex reversal in mice lacking fibroblast growth factor 9. Cell 104: 875-889 (2001).

-Combes AN, Wilhelm D, Davidson T, Dejana E, Harley V, et al: Endothelial cell migration directs testis cord formation. Dev Biol 326: 112-120 (2009)

$\checkmark$ Coveney D, Cool J, Oliver T, Capel B: Four-dimensional analysis of vascularization during primary development of an organ, the gonad. Proc Natl Acad Sci USA 105:7212-7217 (2008).

- Cox JJ, Willatt L, Homfray T, Woods CG: A SOX9 duplication and familial 46, XX developmental testicular disorder. N Engl J Med 364:91-93 (2011).

Crispino JD, Lodish MB, Thurberg BL, Litovsky SH, Collins T, et al: Proper coronary vascular development and heart morphogenesis depend on interaction of GATA-4 with FOG cofactors. Genes Dev 15:839-844 (2001).

Crisponi L, Deiana M, Loi A, Chiappe F, Uda M, et al: The putative forkhead transcription factor FOXL2 is mutated in blepharophimosis/ptosis/epicanthus inversus syndrome. Nat Genet 27:159-166 (2001).

- Cui S, Ross A, Stallings N, Parker KL, Capel B, et al: Disrupted gonadogenesis and male-to-female sex reversal in Pod1 knockout mice. Development 131:4095-4105 (2004).

-Desclozeaux M, Poulat F, de Santa Barbara P, Capony J, Turowski P, et al: Phosphorylation of an N-terminal motif enhances DNAbinding activity of the human SRY protein. J Biol Chem 273:7988-7995 (1998).

-Díaz-Hernández V, León del Río A, Zamora M, Merchant-Larios H: Expression profiles of $S R Y$ and SOX9 in rabbit gonads: the classical model of mammalian sex differentiation. Sex Dev 2:152-166 (2008).

Eicher E, Washburn L, Whitney J, Morrow $\mathrm{K}$ : Mus poschiavinus $\mathrm{Y}$ chromosome in the C57BL/6J murine genome causes sex reversal. Science 217:535-537 (1992).

-Forwood JK, Harley V, Jans DA: The C-terminal nuclear localization signal of the sex-determining region $\mathrm{Y}$ (SRY) high mobility group domain mediates nuclear import through importin $\beta 1$. J Biol Chem 276:46575-46582 (2001). 
Foster JW, Dominguez-Steglich MA, Guioli S, Kwok C, Weller PA, et al: Campomelic dysplasia and autosomal sex reversal caused by mutations in an SRY-related gene. Nature 372:525-530 (1994).

-Garcia-Ortiz JE, Pelosi E, Omari S, Nedorezov T, Piao Y, et al: Foxl2 functions in sex determination and histogenesis throughout mouse ovary development. BMC Dev Biol 9:36 (2009).

$\checkmark$ Gubbay J, Collignon J, Koopman P, Capel B, Economou A, et al: A gene mapping to the sex-determining region of the mouse $\mathrm{Y}$ chromosome is a member of a novel family of embryonically expressed genes. Nature 346: 245-250 (1990).

-Hammes A, Guo J, Lutsch G, Leheste J, Landrock D, et al: Two splice variants of the Wilms' tumor 1 gene have distinct functions during sex determination and nephron formation. Cell 106:319-329 (2001).

-Hanley NA, Hagan DM, Clement-Jones M, Ball SG, Strachan T, et al: SRY, SOX9, and DAX1 expression patterns during human sex determination and gonadal development. Mech Dev 91:403-407 (2000).

-Harley VR, Goodfellow PN: The biochemical role of SRY in sex determination. Mol Reprod Dev 9:184-193 (1994).

-Harley VR, Lovell-Badge R, Goodfellow P, Hextall P: The HMG box of SRY is a calmodulin binding domain. FEBS Lett 391:24-28 (1996).

-Hatano O, Takayama K, Imai T, Waterman M, Takakusu A, et al: Sex-dependent expression of a transcription factor, Ad4BP, regulating steroidogenic $\mathrm{P}-450$ genes in the gonads during prenatal and postnatal rat development. Development 120:2787-2797 (1994).

- Hiramatsu R, Matoba S, Kanai-Azuma M, Tsunekawa N, Katoh-Fukui Y, et al: A critical time window of Sry action in gonadal sex determination in mice. Development 136:129138 (2009).

-Huang B, Wang S, Ning Y, Lamb AN, Bartley J: Autosomal XX sex reversal caused by duplication of SOX9. Am J Med Genet 87:349-353 (1999).

- Jeays-Ward K, Hoyle C, Brennan J, Dandonneau M, Alldus G, et al: Endothelial and steroidogenic cell migration are regulated by WNT4 in the developing mammalian gonad. Development 130:3663-3670 (2003).

Jost A: The age factor in the castration of male rabbit fetuses. Proc Soc Exp Biol Med 66:302 (1947).

Kashimada K, Pelosi E, Chen H, Schlessinger D, Wilhelm D, et al: FOXL2 and BMP2 act cooperatively to regulate follistatin gene expression during ovarian development. Endocrinology 152:272-280 (2011).

Katoh-Fukui Y, Tsuchiya R, Shiroishi T, Nakahara Y, Hashimoto N, et al: Male-to-female sex reversal in M33 mutant mice. Nature 393: 688-692 (1998).
Kaur G, Jans DA: Dual nuclear import mechanisms of sex determining factor SRY: intracellular Ca2+ as a switch. FASEB J 25:665675 (2011).

-Kidokoro T, Matoba S, Hiramatsu R, Fujisawa M, Kanai-Azuma M, et al: Influence on spatiotemporal patterns of a male-specific Sox 9 activation by ectopic Sry expression during early phases of testis differentiation in mice. Dev Biol 278:511-525 (2005).

Kim H, Rimmer K, Kelly S, Ludbrook LM, Clayton $\mathrm{AH}$, et al: Defective calmodulin-mediated nuclear transport of the sex-determining region of the $\mathrm{Y}$ chromosome (SRY) in XY sex reversal. Mol Endocrinol 19:1884-1892 (2005).

Kim Y, Kobayashi A, Sekido R, DiNapoli L, Brennan J, et al: Fgf9 and Wnt4 act as antagonistic signals to regulate mammalian sex determination. PLoS Biol 4:1000-1009 (2006).

Kim Y, Bingham N, Sekido R, Parker K, LovellBadge R, et al: Fibroblast growth factor receptor 2 regulates proliferation and Sertoli differentiation during male sex determination. Proc Natl Acad Sci USA 104:1655816563 (2007).

Kimelman D, Xu W: Beta-catenin destruction complex: insights and questions from a structural perspective. Oncogene 25:74827491 (2006).

Knower K, Kelly S, Harley V: Turning on the male - SRY, SOX9 and sex determination in mammals. Cytogenet Genome Res 101:185198 (2003)

Koopman P, Gubbay J, Vivian N, Goodfellow P, Lovell-Badge R: Male development of chromosomally female mice transgenic for Sry. Nature 351:117-121 (1991).

Kreidberg JA, Sariola H, Loring JM, Maeda M, Pelletier J, et al: WT-1 is required for early kidney development. Cell 74:679-691 (1993).

Lavery R, Lardenois A, Ranc-Jianmotamedi F, Pauper E, Gregoire EP, et al: XY Sox 9 embryonic loss-of-function mouse mutants show complete sex reversal and produce partially fertile XY oocytes. Dev Biol 354:111-122 (2011).

Liu C, Bingham N, Parker K, Yao H: Sex-specific roles of $\beta$-catenin in mouse gonadal development. Hum Mol Genet 18:405-417 (2009).

Lovell-Badge R, Canning C, Sekido R: Sex determining genes in mice: building pathways. Novartis Found Symp 244:4-18 (2002).

Luo X, Ikeda Y, Parker K: A cell-specific nuclear receptor is essential for adrenal and gonadal development and sexual differentiation. Cell 77:481-490 (1994).

Maatouk D, DiNapoli L, Alvers A, Parker K, Taketo $M$, et al: Stabilization of $\beta$-catenin in XY gonads causes male-to-female sex-reversal. Hum Mol Genet 17:2949-2955 (2008).

Manuylov NL, Zhou B, Ma Q, Fox SC, Pu WT, et al: Conditional ablation of Gata4 and Fog2 genes in mice reveals their distinct roles in mammalian sexual differentiation. Dev Biol 353:229-241 (2011).
Matsuda M, Nagahama Y, Shinomiya A, Sato T, Matsuda C, et al: DMY is a Y-specific DMdomain gene required for male development in the medaka fish. Nature 417:559-563 (2002).

Meeks J, Weiss J, Jameson J: Dax1 is required for testis determination. Nat Genet 34:32-33 (2003).

Miyamoto N, Yoshida M, Kuratani S, Matsuo I, Aizawa S: Defects of urogenital development in mice lacking Emx2. Development 124: 1653-1664 (1997).

Moniot B, Declosmenil F, Barrionuevo F, Scherer $\mathrm{G}$, Aritake $\mathrm{K}$, et al: The PGD2 pathway, independently of FGF9, amplifies SOX9 activity in Sertoli cells during male sexual differentiation. Development 136:1813-1821 (2009).

Montazer-Torbati F, Kocer A, Auguste A, Renault L, Charpigny $G$, et al: A study of goat SRY protein expression suggests putative new roles for this gene in the developing testis of a species with long-lasting SRY expression. Dev Dyn 239:3324-3335 (2010).

-Morais da Silva S, Hacker A, Harley V, Goodfellow $\mathrm{P}$, Swain A, et al: Sox9 expression during gonadal development implies a conserved role for the gene in testis differentiation in mammals and birds. Nat Genet 14:62-68 (1996).

Dam JS, Turcotte TJ, Yoon JK: Dynamic expression of R-spondin family genes in mouse development. Gene Expr Patterns 7:306-312 (2007).

Nanda S, DeFalco TJ, Hui Yong Loh S, Phochanukul N, Camara N, et al: Sox100B, a Drosophila group E Sox-domain gene, is required for somatic testis differentiation. Sex Dev 3:26-37 (2009).

Nef S, Verma-Kurvari S, Merenmies J, Vassalli JD, Efstratiadis A, et al: Testis determination requires insulin receptor family function in mice. Nature 426:291-295 (2003).

Nef S, Schaad O, Stallings N, Cederroth C, Pitetti J, et al: Gene expression during sex determination reveals a robust female genetic program at the onset of ovarian development. Dev Biol 287:361-377 (2005).

Ottolenghi C, Omari S, Garcia-Ortiz J, Uda M, Crisponi L, et al: Foxl2 is required for commitment to ovary differentiation. Hum Mol Genet 14:2053-2062 (2005).

Ottolenghi C, Pelosi E, Tran J, Colombino M, Douglass E, et al: Loss of Wnt4 and Foxl2 leads to female-to-male sex reversal extending to germ cells. Hum Mol Genet 16:27952804 (2007).

Pailhoux E, Vigier B, Chaffaux S, Servel N, Taourit $\mathrm{S}$, et al: A 11.7-kb deletion triggers intersexuality and polledness in goats. Nat Genet 29:453-458 (2001)

-Palmer SJ, Burgoyne PS: In situ analysis of fetal, prepuberal and adult $\mathrm{XX} \leftrightarrow \mathrm{XY}$ chimaeric mouse testes: Sertoli cells are predominantly, but not exclusively, XY. Development 112: 265-268 (1991) 
Pannetier M, Tilly G, Kocer A, Hudrisier M, Renault L, et al: Goat SRY induces testis development in XX transgenic mice. FEBS Lett 580:3715-3720 (2006).

- Parma P, Pailhoux E, Cotinot C: Reverse transcription-polymerase chain reaction analysis of genes involved in gonadal differentiation in pigs. Biol Reprod 61:741-748 (1999).

- Parma P, Radi O, Vidal V, Chaboissier M, Dellambra E, et al: R-spondin 1 is essential in sex determination, skin differentiation and malignancy. Nat Genet 38:1304-1309 (2006).

-Payen E, Pailhoux E, Abou Merhi R, Gianquinto L, Kirszenbaum M, et al: Characterization of ovine SRY transcript and developmental expression of genes involved in sexual differentiation. Int J Dev Biol 40:567-575 (1996).

- Pontiggia A, Rimini R, Harley VR, Goodfellow PN, Lovell-Badge R, et al: Sex-reversing mutations affect the architecture of SRY-DNA complexes. EMBO J 13:6115-6124 (1994).

Radi O, Parma P, Imbeaud S, Nasca MR, Uccellatore F, et al: XX sex reversal, palmoplantar keratoderma, and predisposition to squamous cell carcinoma: genetic analysis in one family. Am J Med Genet A 138:241-246 (2005).

-Raymond CS, Parker ED, Kettlewell JR, Brown LG, Page DC, et al: A region of human chromosome 9p required for testis development contains two genes related to known sexual regulators. Hum Mol Genet 8:989-996 (1999).

- Raymond CS, Murphy MW, O’Sullivan MG, Bardwell VJ, Zarkower D: Dmrt1, a gene related to worm and fly sexual regulators, is required for mammalian testis differentiation. Genes Dev 14:2587-2595 (2000).

- Roose J, Molenaar M, Peterson J, Hurenkamp J, Brantjes H, et al: The Xenopus Wnt effector XTcf-3 interacts with Groucho-related transcriptional repressors. Nature 395:608-612 (1998).

Ross AJ, Capel B: Signaling at the crossroads of gonad development. Trends Endocrinol Metab 16:19-25 (2005).

Ross DG, Bowles J, Hope M, Lehnert S, Koopman P: Profiles of gonadal gene expression in the developing bovine embryo. Sex Dev 3: 273-283 (2009).

- Schmahl J, Kim Y, Colvin J, Ornitz D, Capel B: Fgf9 induces proliferation and nuclear localization of FGFR2 in Sertoli precursors during male sex determination. Development 131:3627-3636 (2004).

-Schmidt D, Ovitt C, Anlag K, Fehsenfeld S, Gredsted L, et al: The murine winged-helix transcription factor Foxl2 is required for granulosa cell differentiation and ovary maintenance. Development 131:933-942 (2004).
Sekido R, Lovell-Badge R: Sex determination involves synergistic action of SRY and SF1 on a specific Sox9 enhancer. Nature 453:930-934 (2008).

-Sekido R, Bar I, Narvàez V, Penny G, LovellBadge R: SOX9 is up-regulated by the transient expression of SRY specifically in Sertoli cell precursors. Dev Biol 274:271-279 (2004).

Shen JH, Ingraham HA: Regulation of the orphan nuclear receptor steroidogenic factor 1 by Sox proteins. Mol Endocrinol 16:529-540 (2002).

-Sim H, Rimmer K, Kelly S, Ludbrook LM, Clayton AH, Harley VR: Defective calmodulinmediated nuclear transport of the sex-determining region of the Y chromosome (SRY) in XY sex reversal. Mol Endocrinol 19:18841892 (2005).

Sim H, Argentaro A, Harley VR: Boys, girls and shuttling of SRY and SOX9. Trends Endocrinol Metab 19:213-222 (2008).

- Sinclair A, Berta P, Palmer M, Hawkins J, Griffiths B, et al: A gene from the human sexdetermining region encodes a protein with homology to a conserved DNA-binding motif. Nature 346:240-244 (1990).

-Smith CA, Roeszler KN, Ohnesorg T, Cummins DM, Farlie PG, et al: The avian Z-linked gene $D M R T 1$ is required for male sex determination in the chicken. Nature 461:267-271 (2009).

-Südbeck P, Schmitz ML, Baeuerle PA, Scherer G: Sex reversal by loss of the C-terminal transactivation domain of human SOX9. Nat Genet 13:230-232 (1996).

Swain A, Zanaria E, Hacker A, Lovell-Badge R, Camerino G: Mouse Daxl expression is consistent with a role in sex determination as well as in adrenal and hypothalamus function. Nat Genet 12:404-409 (1998).

- Tevosian SG, Manuylov NL: To beta or not to beta: canonical beta-catenin signaling pathway and ovarian development. Dev Dyn 237: 3672-3680 (2008).

- Tevosian SG, Albrecht KH, Crispino JD, Fujiwara Y, Eicher EM, et al: Gonadal differentiation, sex determination and normal Sry expression in mice require direct interaction between transcription partners GATA4 and FOG2. Development 129:4627-4634 (2002).

-Thevenet L, Méjean C, Moniot B, Bonneaud N, Galéotti N, et al: Regulation of human SRY subcellular distribution by its acetylation/ deacetylation. EMBO J 23:3336-3345 (2004).
Tilmann C, Capel B: Mesonephric cell migration induces testis cord formation and Sertoli cell differentiation in the mammalian gonad. Development 126:2883-2890 (1999).

Tomizuka K, Horikoshi K, Kitada R, Sugawara $\mathrm{Y}$, Iba Y, et al: R-spondin1 plays an essential role in ovarian development through positively regulating Wnt-4 signaling. Hum Mol Genet 17:1278-1291 (2008).

Uhlenhaut NH, Jakob S, Anlag K, Eisenberger T, Sekido R, et al: Somatic sex reprogramming of adult ovaries to testes by FOXL2 ablation. Cell 139:1130-1142 (2009).

-Vainio S, Heikkilä M, Kispert A, Chin N, McMahon A: Female development in mammals is regulated by Wnt-4 signalling. Nature 397: 405-409 (1999).

Verheyen EM, Gottardi CJ: Regulation of Wnt/ beta-catenin signaling by protein kinases. Dev Dyn 239:34-44 (2010).

$\checkmark$ Vidal V, Chaboissier M, de Rooij D, Schedl A: Sox9 induces testis development in XX transgenic mice. Nat Genet 28:216-217 (2001).

$\checkmark$ Wagner KD, Wagner N, Schedl A: The complex life of WT1. J Cell Sci 116:1653-1658 (2003).

Wilhelm D, Martinson F, Bradford S, Wilson M, Combes A, et al: Sertoli cell differentiation is induced both cell-autonomously and through prostaglandin signaling during mammalian sex determination. Dev Biol 287:111-124 (2005).

Wilhelm D, Hiramatsu R, Mizusaki H, Widjaja $\mathrm{L}$, Combes AN, et al: SOX9 regulates prostaglandin D synthase gene transcription in vivo to ensure testis development. J Biol Chem 282:10553-10560 (2007).

-Yao H, Whoriskey W, Capel B: Desert hedgehog/ patched 1 signaling specifies fetal Leydig cell fate in testis organogenesis. Genes Dev 16: 1433-1440 (2002).

-Yao HH, Matzuk MM, Jorgez CJ, Menke DB, Page DC, et al: Follistatin operates downstream of Wnt4 in mammalian ovary organogenesis. Dev Dyn 230:210-215 (2004).

Yao HH, Aardema J, Holthusen K: Sexually dimorphic regulation of inhibin beta $B$ in establishing gonadal vasculature in mice. Biol Reprod 74:978-983 (2006).

-Yoshimoto S, Ikeda N, Izutsu Y, Shiba T, Takamatsu N, et al: Opposite roles of DMRT1 and its W-linked paralogue, DM-W, in sexual dimorphism of Xenopus laevis: implications of a ZZ/ZW-type sex-determining system. Development 137:2519-2526 (2010).

-Yu R, Ito M, Saunders T, Camper SA, Jameson J: Role of Ahch in gonadal development and gametogenesis. Nat Genet 20:353-357 (1998).

-Zanaria E, Bardoni B, Dabovic B, Calvari V, Fraccaro $\mathrm{M}$, et al: $\mathrm{Xp}$ duplications and sex reversal. Philos Trans R Soc Lond B Biol Sci 350:291-296 (1995). 